\section{Guilherme de La Penha: uma história do seu itinerário intelectual em três dimensões}

\author{
Miguel Chaquiam \\ miguelchaquiam@unama.br \\ Tese de Doutorado \\ Programa de Pós-Graduação em Educação \\ Universidade Federal do Rio Grande do Norte \\ Natal (RN) 2012
}

\section{Guilherme de La Penha: a history of his intellectual itinerary in three dimensions}

\author{
Miguel Chaquiam \\ miguelchaquiam@unama.br \\ Doctoral Thesis \\ Post-Graduate Program in Education \\ Federal University of Rio Grande do Norte \\ Natal (Rio Grande do Norte) - Brazil 2012
}

\begin{abstract}
Este estudo tem como foco a historiografia brasileira da ciência, voltado especificamente para a vida e a obra de um matemático-físico da contemporaneidade, e passa a fazer parte do conjunto de pesquisas que investigam, organizam e descrevem itinerários pessoais, intelectuais e profissionais de cientistas e educadores brasileiros. $\bigcirc$ objetivo do estudo foi organizar e descrever a história de vida, formação, atuação profissional e produção científica de Guilherme Maurício Souza Marcos de La Penha. Adotou-se a pesquisa histórica como base teóricometodológica para o desenvolvimento da pesquisa, levantando-se argumentos sobre o perfil de La Penha, para caracterizá-lo como um intelectual múltiplo e para revelar que seu pensamento sobre ciência, tecnologia, formação de cientistas e educadores esteve em harmonia nos seus escritos e na sua prática profissional. Neste sentido, foram considerados os aspectos teóricos relacionados à pesquisa histórica, às biografias, aos itinerários intelectuais, aos arquivos e inventários como fontes e veículos de construção histórica, tendo em vista apontar os elementos essenciais à formação desse perfil transdisciplinar, ou seja, um cientista que exerce a pesquisa, a gestão e a administração, bem como um educador comprometido com o processo formativo e formador. Assim, foi possível assegurar que La Penha teve um perfil intelectual caracterizado como múltiplo e transdisciplinar, o qual defendia a possibilidade de se formar um cientista uno e múltiplo, de atitude não linear e que dialoga com todas as outras áreas, de modo a ser compreendido sob um modelo de cientista para o século XXI. Esse modelo foi claramente inspirado nos autores com os quais La Penha se identificou ao longo da sua formação e atuação profissional, a exemplo dos três que mais se destacaram na sua relação científica: Arquimedes, Leonhard Euler e Clifford Ambrose Truesdell.
\end{abstract}

The research focuses the Brazilian historiography of science, specifically on the life and work of a contemporaneous mathematician-physicist. It is part of the set of investigations that analyze, organize and describe personal, intellectual and professional itineraries of Brazilian scientists and educators. The research organizes and describes life history, education, professional experience and scientific production of Guilherme Maurício Souza Marcos de La Penha. We adopted the historical method for the development of this study, rising arguments about the profile of La Penha as a multiskill intellectual and revealing that his thoughts about science, technology, training scientists and educators were in accordance with his writings and professional practice. We considered theoretical aspects related to historical research, biographies, intellectual itineraries, archives and inventories as sources and media for historical construction, in order to point out the essential elements of this transdisciplinary profile, in other words, a scientist who carries out the research, management and administration, as well as a committed educator to the on-going training and forming process. Thus, it was possible to ensure that La Penha was a multi- and transdisciplinary intellectual who defended the possibility of forming, at the same time, a unique and multiple scientist, with non-linear behavior and who knows to dialogue with other fields - in order to be understood under a model of scientist for the 21st century. This model was clearly inspired by authors who La Penha admired throughout his training and professional activities, such as the three most important: Archimedes, Leonhard Euler and Clifford Ambrose Truesdell. 